\title{
Recalling the 16th IGC, Washington 1933
}

\author{
by Thomas B. Nolan and Marie Siegrist
}

As preparations continue for the 1989 IGC and at the end of this collection of articles on the geology of the U.S.A., it is fitting to look back briefly to the last Congress held in the U.S.A. In 1933, 665 geologists from 54 countries and territories attended the 16th IGC, also in Washington. Among the organizers were the authors of this article, which shows how a major scientific meeting was run half a century ago.

\section{Looking Back to 1933: An Early Crisis}

Our first reaction to the recently received First Circular of the 28th Session of the International Geological Congress, to be held in Washington, D.C. in 1989, was one of awe over the magnitude of the arrangements that are now required relative to those made for the 16th IGC held here in Washington in 1933. Primarily these are due to the increase in the number of individuals who are expected to attend, but perhaps equally significant are the much broader scope of the program, and the much more complex problems of adequate facilities and travel arrangements for field trips.

The 16th IGC was originally scheduled to convene in Washington in 1932. Preparatory work began shortly after the closing session of the 15th Congress under the leadership of the President Waldemar Lindgren (Massachusetts Institute of Technology), the General Secretary W.C. Mendenhall (then Director USGS, Fig. 1), the Assistant Secretaries Henry G. Ferguson (USGS) and Marcus I. Goldman (both from the USGS), and the Treasurer E.B. Matthews (Johns Hopkins University). In the early stages of the organizational work these officers recruited help, most of it on a volunteer basis with no pay, from colleagues and students throughout the country.

On a Geological Survey project in California many years earlier, Prof. Lindgren had as an assistant Herbert Hoover, who in the meantime had become President of the United States. As a result of this old link, Hoover had made arrangements for obtaining a sizable (for those days) grant from the Federal Congress to cover the costs of organizational preparations for the Geological Congress. As the fates would have it, however, the stock market erashed, Hoover was defeated for re-election as President, and the new Congress, in the face of the 1933 depression, refused to appropriate the planned funds.

As it became obvious that no major official funding for the meeting would be forthcoming, the volunteer assistants ceased their activity, and a part-time student-clerk (M.S.), who had been hired in the early thirties, was terminated, and plans for dealing with indefinite postponement of the Congress began.

\section{Rescued by the GSA}

At this time the Geological Society of America (GSA) came to the rescue, as a result of a large bequest from R.A.F. Penrose. The Society turned over $\$ 90,000$ of the bequest to the IGC, making it possible for the Congress of ficers to pick up the pieces and to make definite plans for holding the meeting in 1933, only a year later than originally scheduled.
The same part-time clerk was rehired, and assisted Mendenhall in Washington and the New York Committee at the GSA headquarters, and later, Marcus Goldman (Fig. 2) on both the arrangements for the Washington program and later with the publication of the reports by GSA.

Two graduate students from the Johns Hopkins University, Raymond C. Becker and Shailer Philbrick, were appointed as assistants to the Congress officers. Becker, who had had some experience in dealing with railroad travel, provided Ferguson with help in the arrangements for field trips. Philbrick assisted Matthews in various facets of the Treasurer's duties. When the part-time workers became fulltime employees, Becker was made Business Manager for the Congress. Other cash contributions were received, and through the Geological Survey the U.S. Government provided approximately $\$ 50,000$ to cover the cost of preparation and printing of the field-trip guidebooks and the engraving and printing of the geological map of the U.S.A.

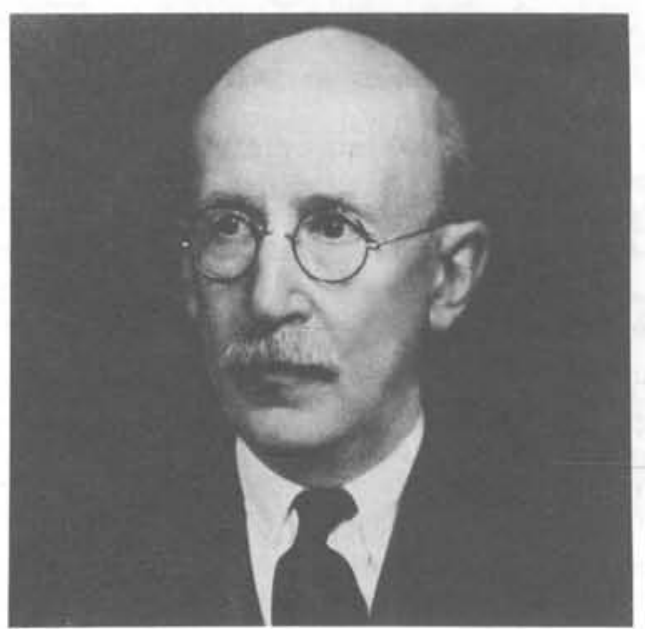

Figure 1: W.C. Mendenhall, General Secretary of the 16th IGC and Director of the USGS.

When the officers had once again set the machinery in motion, the plans for the technical sessions and field trips progressed quickly, with no more than the usual turmoil and crises associated with such an undertaking. At the expense of their careers, the two Assistant Secretaries devoted all their time and energy to making sure that the Congress would be the success that it was. The program for the technical sessions, as well as the subsequent publication of the two-volume report of the Congress, was largely the responsibility of Marcus Goldman. The planning and arrangements for field trips and the publication of field-trip guidebooks were under the direction of Henry Ferguson.

In the thirties, travel by air was the exception rather than the rule. A special office was set up in the GSA's headquarters, housed at that time on the grounds of Columbia 
University, to greet and complete registration of foreign geologists scheduled to arrive by ship in the New York harbor from Europe and elsewhere. About two weeks before the opening session of the Congress the files for these registrants went up from Washington to this office, together with the now full-time clerk. The Treasurer, E.B. Matthews, and his assistant went up from Baltimore to handle the money transactions. The office was under the supervision of C.P. Berkey, then Secretary of GSA.

\section{Overseas Delegates Arrive}

With the help of an assortment of professors and graduate students, who went down to the docks to meet the foreign visitors, the staff of the so-called New York office managed to get the registrants to the pre-Congress field trips for which they had registered or on their way to their hotels in Washington. The whole operation went quite smoothly in spite of language barriers, last-minute changes requested by registrants, and unforeseen problems. In addition to

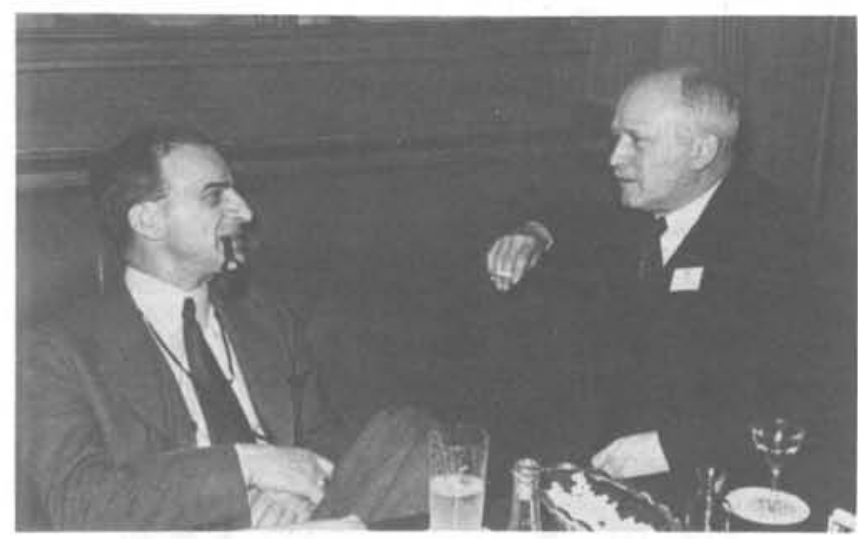

Figure 2: Marcus Goldman (left), one of the two Assistant Secretaries of the 1933 Congress, in conversation with W.H. Bucher (Columbia University).

services directly connected with registration, other kinds of help were given, such as finding a dentist late at night to relieve the toothache of an Hungarian geologist who could speak German but no English. The clerk (M.S.) was the only dinner partner of members of one of the foreign delegations at a restaurant where there was dining and dancing, though she never had a bite to eat! And personal tours were conducted to the top of the Empire State building.

In addition to the longer pre-Congress, excursions that originated in New York, there was a series of one-day excursions, prepared by the New York Committee, to observe the geological features of New York City, Franklin Furnace, the Passaic Valley, and other nearby areas, each for a fee of $\$ 2.00$. There were also two 2-day trips, one to study the stratigraphic and structural geology of the Hudson-Catskill region, and the other to observe the engineering geological structures of New York City. In Washington, similar but much more intense activity was taking place, largely because of the greater number of pre-registered participants and the greater variety of preand post-Congress excursions, most of which originated in Washington.

Ferguson, with the assistance of Becker, had as a major responsibility, the arrangements for the two post-Congress transcontinental trips. It is perhaps difficult for many of us today to appreciate fully the problems of travel by transcontinental railroad and, for the local trips, by bus or private car. The transcontinental train trips, involving the use of sleeping ears, required not only careful scheduling, but also a certain amount of diplomacy in such matters as the assignment of upper and lower berths. Some of the planning and physical arrangements for the field trips were given major support (both fiscal and social) by mining and petroleum companies.

All general, section, and council meetings were held in the then recently constructed Chamber of Commerce building, located a short distance north of the White House. It was convenient to downtown hotels and only a few blocks from the Geological Survey headquarters, located at that time in the Interior Department building at 18 th and F Streets, N.W.

\section{Science at the 16th IGC}

The lapse of 50 years has left us, we must confess, with very little recall of the scientific content of the papers that were presented in the different sections. We have blurred recollections that the topics of some of the papers were controversial, such as the tools for the measurement of geological time, the mechanism of crustal movements, the genesis of metallic ores, and the position of the CarboniferousPermian boundary. Many papers gave general summaries of the status of knowledge of the geology of different countries around the world or the principles of various theories; others dealt with more specialized subjects such as fossil man, the geology of petroleum, processes and landforms in arid regions, and the geology of copper deposits. (Editor's note: Table 1 is a selection of some of the more important papers presented at the 1933 IGC.)

Considerable effort had been made during preparation of the program for the technical sessions to incorporate papers by leading proponents of prevailing theories. Although it cannot be said to have been prevailing, the theory of continental drift had generated a certain amount of interest (mostly negative). Several letters were sent to Wegener asking him to speak at the Congress. There never was a reply. It was learned much later that he had died in Greenland in 1930.

Most of the papers were presented before relatively small audiences in the smaller rooms of the Chamber of Commerce building. This was productive of spirited discussions in many instances, occasionally handicapped by language problems. An outstanding exception to the language-barrier problem was provided by President Lindgren. In his closing address in the large hall of the building he delivered his remarks in English, French, German, and Spanish.

\section{TABLE 1:}

\section{A SELECTION OF SCIENTIFIC HIGHLIGHTS PRESENTED AT THE 16 TH IGC*}

Rating the geological clock - A.C. Lane (U.S.A.)

Residual magnetism and the measurement of geologic time - J.G.Koenigsberger (Germany)

Plutone und ihre Stellung im Rahmen der Krustenbewegung - H. Cloos (Germany)

Hypogene zoning in metalliferous lodes - W.H. Emmons (U.S.A.)

The Lower Paleozoic rocks of Britain - O.T. Jones (U.K.)

Oscillation or Pulsation - A.W. Grabau (China)

The division of the late Paleozoic formations of Gondwanaland - A.L. du Toit (South Africa)

Geomorphology of mountainous deserts - W. M. Davis (U.S.A.)

The framework of Eastern Asia - J.S. Lee (China)

The undation theory of the development of the

Earth's crust - R.W. van Bemmelen (Java)

Cryptovolcanic structures of the United States W.H. Bucher (U.S.A.)

*All published in the two-volume proceedings of the Congress. (Selection by Editor.) 
As is frequently the ease, the lively interchanges of pros and cons in the discussion periods became conversation pieces, some of which have persisted to this day. Remarks made by colorful "deans of science" enlivened many of the discussions. Andrew Lawson (University of California at Berkeley) and A.C. Lane (MIT) were known to lock horns frequently. They did so during discussions of papers in several sections. Once Lane went so far, however, to admit that he had treated some of the ideas about the measurement of geological time in a "stepmotherly" fashion.

Some of the discussion periods gave rise to new ideas that were subsequently developed or rejected. Many suggestions were made, such as the one by R.A. Daly (Harvard University), which was a plea for exact definition of the term "batholith", on grounds that, according to him, most of the magmatic bodies deseribed in the section on batholiths did not fit into this eategory.

\section{The Main Legacy}

The most lasting benefit of the 16th IGC, as is probably true of other Congresses, was in the opportunities provided by the meeting sessions, social gatherings, and especially the field trips for geologists of countries all over the world to become acquainted with one another. Through these encounters it became possible to acquire a better understanding of various problems and what had seemed to be differences. Friendships were formed that continued through correspondence and, in some cases in later years, in personal visits.

For some of the younger geologists who were in attendance in Washington or who were participants in the field trips, it was also an opportunity to come face-to-face with some of the well-known senior geologists, both American and foreign, who were known only through their writings or their reputations.
Fifty five years later we marvel at what has happened to the geological sciences in the interim. We are grateful to be able to attend the 1989 Congress, and equally grateful that we do not have to organize it.

Dr. T.B. Nolan (2219 California St. NW, Washington, DC 20008) won the Spendiarov Prize at the 1933 Congress, awarded to a promising young geologist of the host country. Calvin Coolidge was President of the U.S.A. when Dr. Nolan began his eareer with the USGS in 1924. He was its director from 1956 to 1965 when he stepped down to resume his research. A member of the group that originally organized IUGS, he was a Union Vice-President from 1964 to 1972.

Marie Siegrist (2716 Ordway St., N.W., Washington, DC 20008) was a key member of the organizing committee for the 1933 IGC. She worked for the Geological Society of America for nearly 40 years, during most of which time she edited the well-known Bibliography and Index of Geology Exclusive of North America.
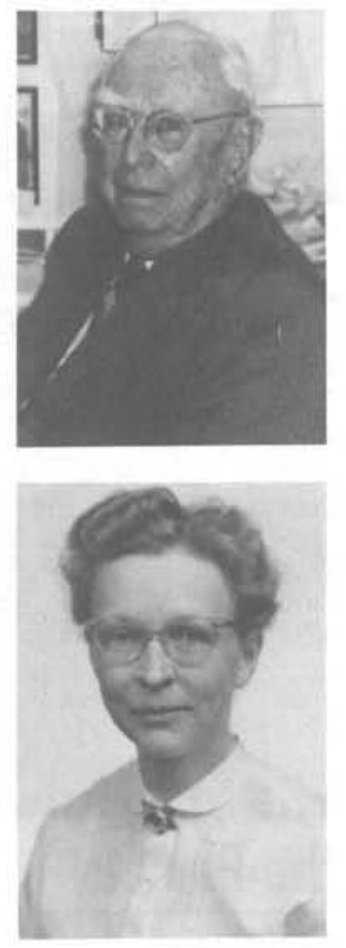

\section{LIST OF ABBREVIATIONS}

(Others are identified in the text or in Directory of IUGS Bodies)

\begin{tabular}{|c|c|}
\hline AAPG & American Association of Petroleum Geologists \\
\hline AEG & Association of Exploration Geochemists \\
\hline AEGS & Association of European Geological Societies \\
\hline AGI & American Geological Institute \\
\hline AGID & $\begin{array}{l}\text { Association of Geoscientists for International } \\
\text { Development }\end{array}$ \\
\hline AIME & American Institute of Mining Engineers \\
\hline AIPG & American Institute of Professional Geologists \\
\hline $\mathrm{CCOP}$ & $\begin{array}{l}\text { Committee for Co-ordination of Joint } \\
\text { Prospecting for Mineral Resources in Asian } \\
\text { Offshore Areas }\end{array}$ \\
\hline CGMW & Commission for the Geological Map of the World \\
\hline COCORP & Consortium for Continental Reflection Profiling \\
\hline CODATA & $\begin{array}{l}\text { ICSU Committee on Data for Science and } \\
\text { Technology }\end{array}$ \\
\hline CRER & Cretaceous Resources, Events and Rhythms \\
\hline DNAG & Decade of North American Geology \\
\hline DOSECC & $\begin{array}{l}\text { Deep Observations and Sampling of the Earth's } \\
\text { Continental Crust }\end{array}$ \\
\hline ESCAP & $\begin{array}{l}\text { UN Economic and Social Commission for Asia } \\
\text { and the Pacific }\end{array}$ \\
\hline GSA & Geological Society of Africa \\
\hline GSA & Geological Society of America \\
\hline GSGP & Global Sedimentary Geology Program \\
\hline HVO & Hawaiian Volcano Observatory \\
\hline IAG & International Association of Geodesy \\
\hline IAGA & $\begin{array}{l}\text { International Association of Geomagnetism and } \\
\text { Aeronomy }\end{array}$ \\
\hline IAGC & $\begin{array}{l}\text { International Association of Geochemistry and } \\
\text { Cosmochemistry }\end{array}$ \\
\hline
\end{tabular}

IAGOD

IAH

IAS

IASPEI

IA VCEI

ICL

ICSU

IGC

IGBP

IGCP

IMA

INQUA

IRIS

IUGG

IUGS

JOI

MEGS

NAS

NASA

NRC

NSF

ODP

SEDI

SEG

SGA

SMI

TWARS

WDC

UNESCO

USGS

WOVO
International Association on the Genesis of Ore Deposits

International Association of Hydrogeologists International Association of Sedimentologists International Association of Seismology and Physics of the Earth's Interior

International Association of Volcanology and Chemistry of the Earth's Interior

Inter-Union Commission on the Lithosphere International Council of Scientific Unions International Geological Congress International Geosphere-Biosphere Programme International Geological Correlation Programme International Mineralogical Association International Union for Quaternary Research Incorporated Research Institutions for Seismology

International Union of Geodesy and Geophysies International Union of Geological Sciences Joint Oceanographic Institutions Meeting of the European Geological Societies National Academy of Sciences National Aeronautics and Space Administration National Research Council National Science Foundation Ocean Drilling Program Study of the Earth's Deep Interior Society of Economic Geologists Society for Geology Applied to Mineral Deposits Small Mining International

Third World Association for Remote Sensing World Data Centre

United Nations Educational, Scientific and Cultural Organization

United States Geological Survey World Organization of Volcano Observatories 


\section{NEW EARTH SCIENCE TITLES FROM}
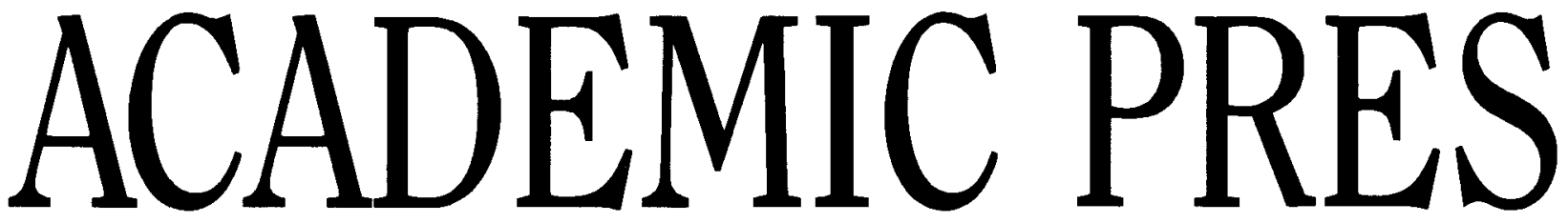

\section{The Earth's Core} Second Edition

\section{J.A. Jacobs}

CONTENTS: General Physical Properties of the Earth. The Origin of the Core. The

Thermal Regime of the Earth's Core. The Earth's Magnetic Field. The Constitution of the Core. The Cores of Other Planets. 1987, 304 pages, \$65.00/ISBN: 0-12-378951-6

\section{The Structure of the Planets}

\section{John W. Elder}

CONTENTS: Prologue. The Hydrogen Era: Gestation of the Planets. Evolution of the Hydrogen Bodies. Parturition of the ProtoTerrestrial Planets. The Geological Era: Onset of Geological Time. Chemical Development. Physical Development. Thermal History. Appendices. References.

Index.

1987, 210 pages, \$49.50/ISBN: 0-12-236452-X

\section{Principles of Ocean Physics}

\section{J.R. Apel}

CONTENTS: Physical Oceanography: An Overview. Forcing Functions and Responses. Hydrodynamic Equations for the Sea. Thermodynamics and Energy Relations. Geophysical Fluid Dynamics I: Waves and Tides. Geophysical Fluid Dynamics II: Currents and Circulation. Acoustical Oceanography. Electromagnetics and the Sea. Optics of the Sea. Appendices. Index. In Paperback: \$35.00/ISBN: 0-12-058866-8 Casebound: $\$ 68.50 / I S B N$ : 0-12-058865-X 1987, 648 pages

\section{Mantle Metasomatism}

edited by Martin A. Menzies

and Chris J. Hawkesworth

This volume makes a comprehensive contribution to the study of metasomatic and enrichment processes, their origin and their importance in determining trace element and isotopic heterogeneity in the lithospheric mantle.

1987, 472 pages, \$76.50/ISBN: 0-12-491080-7

\section{Dynamical Geology of Salt and Related Structures}

edited by I. Lerche and J.J. O'Brien

CONTENTS (Section Headings): Salt Structures. Structural Impact of Salt on Surrounding Formations. Caprock. Fluid Flow, Salt Dissolution, Heat Flow, and $\mathrm{Hy}$ drocarbon Migration. Index.

1987, 832 pages, $\$ 49.50 / I S B N$ : 0-12-444170-X

\section{Aeolian Dust and Dust Deposits}

\section{K. Pye}

CONTENTS: The General Nature and Significance of Windborne Dust. Mechanisms of Fine Particle Formation. Dust Entrainment, Transport and Deposition. Dust Sources, Sinks and Rates of Deposition. Dust Transporting Wind Systems. Grain Size, Mineralogy and Chemical Composition of Aeolian Dust. Implications of Dust Deflation, Transport and Deposition. Dust Deposition in the Oceans. Loess. Index.

In Paperback: $\$ 29.50 / I S B N$ : 0-12-568691-9 Casebound: \$59.50/ISBN: 0-12-568690-0 1987, 352 pages

\section{Geomagnetism}

Volumes 1 and 2

edited by J.A. Jacobs

VOLUME 1 CONTENTS: Historical Introduction to Geomagnetism. General Instrumentation. Instrumentation and $\mathrm{Ex}$ perimentation. The Main Field. The Crustal Field. Index.

1987,450 pages, \$112.00/ISBN: 0-12-378671-1

VOLUME 2 CONTENTS: Magnetohydrodynamics of the Earth's Core. Origin of the Main Field: Kinematics. Theory for the Origins of Field-Dynamic Aspects. Lunar Paleomagnetism. Planetary Magnetism. Magnetism of Meteorites. Index.

1987, 586 pages, \$112.00/ISBN: 0-12-378672-X

\section{The Techniques of Modern Structural Geology \\ Volumes 1 and 2}

John G. Ramsay and Martin I. Huber

Volume 1

In Paperback: \$25.00/ISBN: 0-12-576921-0 Casebound: $\$ 55.00 / I S B N$ : 0-12-576901-6

1983, 307 pages

Volume 2

In Paperback: $\$ 34.50 /$ ISBN: 0-12-576922-9 Casebound: $\$ 70.00 /$ ISBN: $0-12-576902-4$ 1987, 400 pages

\section{Fracture Mechanics of Rocks}

edited by B.K. Atkinson

1987, 600 pages, \$96.00/ISBN: 0-12-066265-5

\section{APACADEMIC PRESS}

